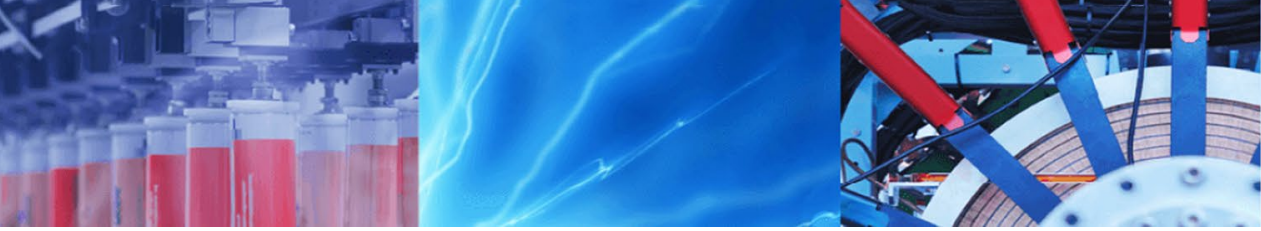

Research Article

\title{
Proposed models for concrete thermal expansion with different aggregate types and saturation conditions
}

\author{
Mohamed Ghannam ${ }^{1}$ (D) \\ (c) Springer Nature Switzerland AG 2019
}

\begin{abstract}
The Coefficient of thermal expansion (CTE) for concrete is one of the most important parameters that affect the fire performance of concrete. Concrete's coefficient of thermal expansion is controlled by the CTE of each component of the concrete mix, as the coarse aggregates represent the largest portion in the concrete mix, it is considered to have a significant effect on the CTE for concrete. Another factor that affects concrete's CTE significantly is the saturation condition (saturated, partially saturated and oven dried condition). This paper presents reviews for available tests results that have been conducted on the CTE for concrete at elevated temperatures for different aggregates type, these results are used to evaluate the models proposed by ASCE model and Euro Code. The results included the coefficient of thermal expansion for different types of aggregates in different saturation conditions (saturated, partially saturated and oven dried condition). It is found that there is a significant difference between the experimental results and Euro code carbonate model, Euro code siliceous model and ASCE. New models were proposed for predicting CTE of different types of aggregate under different saturation condition. The newly proposed models give better prediction compared to Euro code and ASCE model.
\end{abstract}

Keywords Coarse aggregate - Saturation condition · Proposed model · Coefficient of thermal expansion (CTE) · Eurocode and ASCE

\section{Introduction}

Fire is considered to be one of the most vital incidents that can leave many casualties in human life and buildings or structures. The increase in using concrete in different types of structures leads to the need to understand fire behaviour of concrete [1], One of the most important factors that affects the fire behaviour of concrete is the coefficient of thermal expansion.

The coefficient of thermal expansion (CTE) represents the change of a material volume as a result of a change in temperature and is expressed as a change in length per degree of temperature change. The coefficient of thermal expansion is important as it represents the structural movement and thermal stresses resulting from a change in temperature which may lead to concrete cracking and spalling.

Concrete's coefficient of thermal expansion is a combination of thermal expansion of the main components of concrete (aggregate and cement paste), each of these component has its own CTE. CTE has some effects on concrete, as an example: moisture content change, volume change, and dehydration as a result of water evaporation. Micro-stresses and micro-cracking are considered from the harmful effects that can be caused as a result of the big difference in CTE of aggregate and cement [2].

Some researchers used a constant value for concrete CTE as stated in Hong, Varma [3] and Espinos et al. [4]. Also, AIJ [5] assumed a constant value of concrete CTE. Some other models as Eurocode-4 [6] and ASCE [7] stated that

$\triangle$ Mohamed Ghannam, m.ghannam@mans.edu.eg|'Structural Engineering Department, Faculty of Engineering, Mansoura University, Mansoura, Dakahlia 35516, Egypt.

SN Applied Sciences (2019) 1:425 | https://doi.org/10.1007/s42452-019-0452-1

Received: 26 February 2019 / Accepted: 2 April 2019 / Published online: 6 April 2019 
concrete's coefficient of thermal expansion is temperature dependent. Eurocode-4 [6] used different equations for CTE for concrete based on the type of coarse aggregate (carbonate and siliceous aggregate), however, ASCE [7] used the same equation for CTE for all types of aggregate under different saturation conditions.

From the above discussion, it was very important to evaluate the available concrete CTE models at different elevated temperatures.

In this paper, reviews for available tests results that have been conducted on the concrete CTE at elevated temperatures are presented. The models proposed by ASCE model and Euro Code are evaluated using the available test data of CTE. The data included the CTE for different types of aggregates (Limestone, Dolomite, Basalt and Diabase, Quartzite and Sandstone aggregate) in different saturation conditions (saturated, partially saturated and oven dried condition). Usually, the saturated condition is used for studying the fire behavior of concrete filled steel tube (CFST) columns where steel tube acts as a shield from evaporating water from inside concrete. Partially saturated can be used in concrete structure or steel encased section where concrete is exposed to the atmosphere.

From the comparison between the available model and the test results, a significant difference is observed between the experimental results and Euro code carbonate model, Euro code siliceous model and ASCE. Based on the result of this comparison, new models were proposed for predicting CTE of different types of aggregate under different saturation condition. The newly proposed models give a better prediction for CTE compared to Euro code and ASCE model.

\section{Coarse aggregates in concrete}

Aggregates represent more than $70 \%$ of concrete volume. Two-third of the aggregate is composed of coarse aggregates [8]. As a result, coarse aggregate plays an important role in determining the CTE of concrete [9].

In this paper coarse aggregate is given special attention as it has a significant effect in determining the concrete CTE. Many standards, codes, and researchers divided coarse aggregate of concrete into siliceous concrete which contains mainly of Silica $\left(\mathrm{SiO}_{2}\right)$ and carbonate concrete which contains mainly Lime (CaO). Actually, it is difficult to do this differentiation for all types of concretes, as some aggregate consists of a combination of Silica $\left(\mathrm{SiO}_{2}\right)$ and Lime ( $\mathrm{CaO})$. Table 1 gives the chemical composition of some aggregates used in concrete mixes as were published in previous researches. Table 2 gives the most important definition for the chemical symbols used in Table 1.
As can be seen from Table 1, Quartize and granite can be grouped as a siliceous aggregate as they contain mostly silica $\left(\mathrm{SiO}_{2}\right)$ while Dolomite and limestone can be considered as a carbonate aggregate as they contain mainly Lime $(\mathrm{CaO})$, all other types of aggregates can hardly be grouped in siliceous or carbonate aggregate as the contains both a considerable portion of Silica and Lime, so it is very important to accurately evaluate the available expansion models against the test results of CTE of these types of aggregates, this step is briefly discussed in the next two Sects.

\section{Factors affecting concrete thermal expansion}

The available previous researches and tests result that have been done on the concrete CTE are collected, and presented in Table 3.

From previous researches that were performed on the concrete CTE, it can be concluded that the major factors that affect significantly the CTE of concrete are: Aggregate type and content (especially the coarse aggregate), the temperature level and the moisture content. A brief discussion about each factor that affects concrete CTE is indicated in the next subsections.

\subsection{Aggregate type and content}

The CTE of concrete is a composition of aggregates expansion and cement paste shrinkage. Cement paste shrinkage is due to the dehydration occurred during temperature rise as a result of heating. Aggregates expansion is more significant than cement paste shrinkage so that the CTE increases monotonically with temperature, [26, 30].

As mentioned before coarse aggregate has a significant role in determining CTE of concrete as a result of its large portion in the concrete mix [32-34]. As the aggregate type influences concrete CTE $[2,12,23,35]$, selection of an aggregate with a low coefficient of thermal expansion may help to prevent crack formation in concrete as a result of less expansion [30]. Aggregates which composed mainly of carbonate (e.g. limestone) have a low value of coefficients of thermal expansion [33, 34]. Khoury et al. [36] stated that CTE of different concrete mixes that contain different aggregate type are significantly different from each other even if these aggregates have the same volume percentage of the concrete mix.

Concrete containing Quartz (in fine or coarse aggregate) has a remarkable increase in expansion at about $573^{\circ} \mathrm{C}$ due to the Alfa to Beta conversion of quartz [12, $14,26,35,37]$. For the carbonate aggregate, the CTE increases with temperatures above $500^{\circ} \mathrm{C}$. This is a result of dolomite dissociation in carbonate aggregate [35]. At a temperature above 850 and $900{ }^{\circ} \mathrm{C}$, the thermal strain 


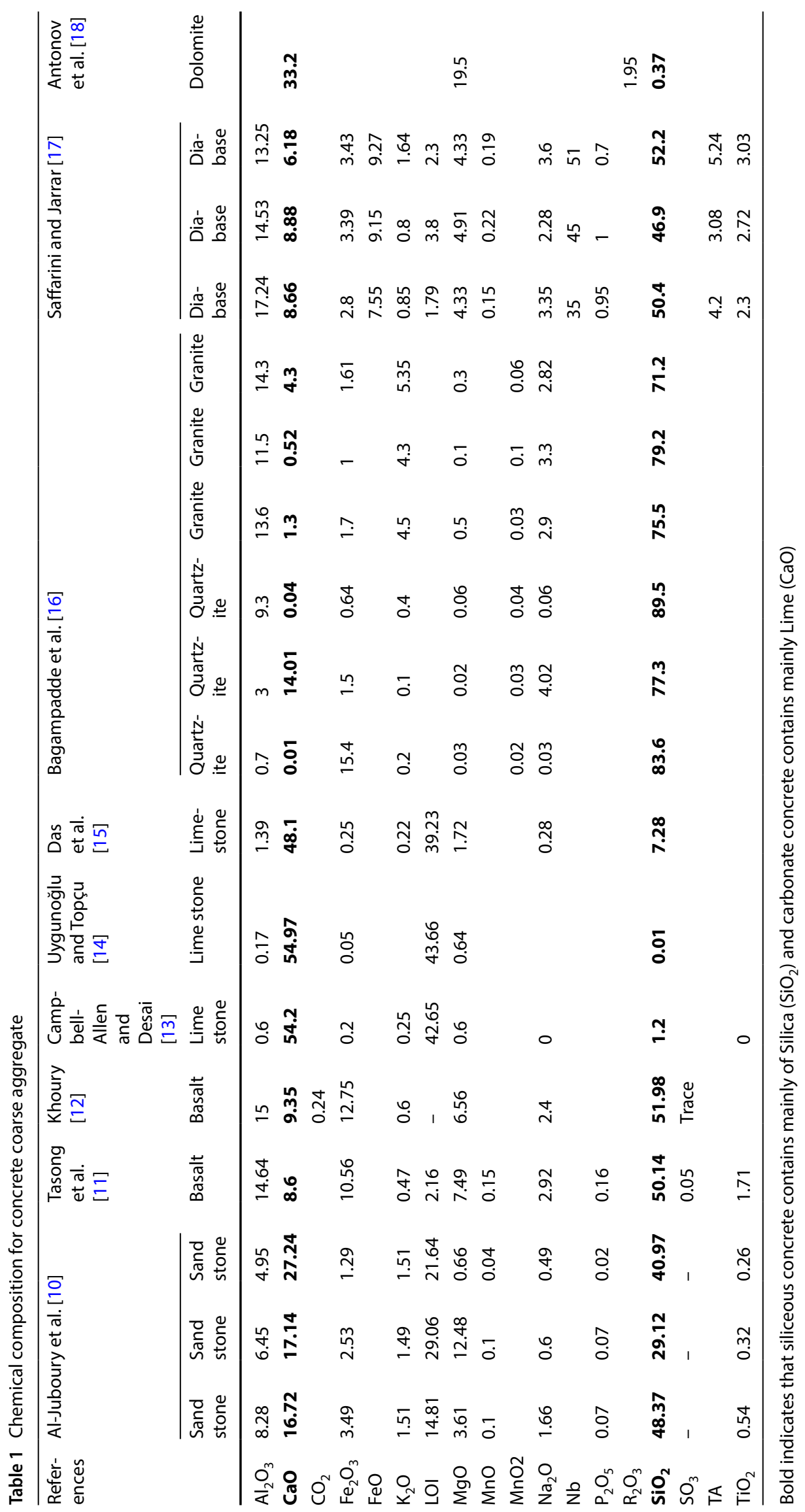


Table 2 Definition for the chemical symbol

\begin{tabular}{ll}
\hline Symbol & Definition \\
\hline$(\mathrm{CaO})$ & Lime \\
$\left(\mathrm{SiO}_{2}\right)$ & Silica \\
$\left(\mathrm{AL}_{2} \mathrm{O}_{2}\right)$ & Alumina \\
$\left(\mathrm{Fe}_{2} \mathrm{O}_{3}\right)$ & Ferric oxide \\
$\left(\mathrm{MgO}^{2}\right)$ & Magnesia \\
$\left(\mathrm{SO}_{3}\right)$ & Sulphuric anhydride \\
$\left(\mathrm{K}_{2} \mathrm{O}\right)$ & Potassium oxide \\
$\left(\mathrm{Na}_{2} \mathrm{O}\right)$ & Sodium oxide \\
$\left(\mathrm{CO}_{2}\right)$ & Carbonic \\
$\mathrm{LO}$ & Loss on ignition \\
\hline
\end{tabular}

suddenly reduced due to the deformation of the cement matrix's crystal structure [14]. CTE of the plain concrete declines above a temperature of $800^{\circ} \mathrm{C}$, as a result of concrete shrinkage and dehydration [35].

Naus [2] indicated that there is an increase in the coefficient of thermal expansion for limestone concrete until calcium carbonate $(\mathrm{CaCO} 3)$ decomposed to calcium oxide $(\mathrm{CaO})$ and carbon dioxide (decarbonation). After decarbonation occurs, the coefficient of thermal expansion experiences a decrease in its value.

\subsection{The temperature level}

Concrete CTE is a nonlinear function of temperature and increases with increasing temperature, this fact was proved by many previous researchers and standers $[12$, $23,32,36-40]$.

\subsection{The moisture content}

The moisture content of the concrete has an effect on the concrete CTE especially at a temperature less than $200^{\circ} \mathrm{C}$, as a result of evaporation of free and the bond water [2, $23,32,34,37]$. CTE will reach its minimum value at a temperature around $(150-200){ }^{\circ} \mathrm{C}$, due to moisture loss and water evaporation which will occur at that range $[12,32]$.

The concrete CTE for oven-dry concrete is slightly higher than saturated concrete $[37,40,41]$ due to the drying shrinkage which reduces the apparent expansion in case of saturated concrete.

The partially saturated concrete (50-80\% humidity) has the highest CTE coefficient compared to other curing state of concrete (oven-dry and saturated state $(100 \%$ humidity)). Sakyi-Bekoe [40] stated that Neville, Brooks [39] and Mindess et al. [41] explain this behaviour as a result of two types of thermal expansion that occurs in case of partially saturated concrete. The first one is the kinetic or the true thermal coefficient, which occurs due to the molecular movement of the paste, the second one is the hygro-thermal expansion coefficient. The hygro-thermal expansion coefficient occurred as a result of increased water vapour pressure as the temperature increases. Hygrothermal expansion does not occur when the paste is totally dry or when it is saturated, as there can be no increase in the water vapour pressure.

\section{Available models}

The most widely used available models for concrete CTE is the ASCE [7] model and Eurocode-4 [6] models for siliceous and carbonate aggregate concrete. ASCE model is indicated in Eq. (1) while Euro code-4 models for siliceous and carbonate aggregate concrete are indicated in Eqs. 2 and 3 respectively. Both models (ASCE and Euro code-4) are clearly indicated in Fig. 1.

$$
\begin{aligned}
\varepsilon_{\mathrm{th}}= & \left(0.004 \mathrm{~T}^{2}+6 \mathrm{~T}-121.6\right) * 10^{-6} \\
\varepsilon_{\mathrm{th}}= & -1.8 * 10^{-4}+9 * 10^{-6} \mathrm{~T} \\
& +2.3 * 10^{-11} \mathrm{~T}^{3} \quad 20^{\circ} \mathrm{C} \leq \mathrm{T} \leq 700^{\circ} \mathrm{C}
\end{aligned}
$$

$\varepsilon_{\text {th }}=14 * 10^{-3} \quad 700^{\circ} \mathrm{C}<\mathrm{T} \leq 1200^{\circ} \mathrm{C}$

$\varepsilon_{\mathrm{th}}=-1.2 * 10^{-4}+6 * 10^{-6} * \mathrm{~T}$

$$
+1.4 * 10^{-11} \mathrm{~T}^{3} \quad 20^{\circ} \mathrm{C} \leq \mathrm{T} \leq 805^{\circ} \mathrm{C}
$$

$\varepsilon_{\text {th }}=12 * 10^{-3} \quad 805^{\circ} \mathrm{C}<\mathrm{T} \leq 1200^{\circ} \mathrm{C}$

\section{Evaluating available models for CTE}

In this section, the most widely used available models (Euro code and ASCE models) are evaluated against test results of CTE that have been done previously, as it was clear from the literature review that the coarse aggregate type has a significant effect on the concrete CTE. Based on that conclusion, the test results obtained from the experimental program shown in Table 3 were first grouped according to the coarse aggregate type after that, these test results were compared with the Euro code and ASCE models in separate figures according to the concrete coarse aggregate type as indicated in Figs. 2, 3, 4, 5, 6, 7, $8,9,10$. The following paragraphs show the comparison between the CTE obtained from the experimental programs that are shown in Table 3 against CTE obtained from Euro code and ASCE models.

Figure 2 represents the comparison for the CTE of Limestone aggregate concrete $[12,14,19,20,31,32]$, it can be found that Euro code carbonate model gives an upper 


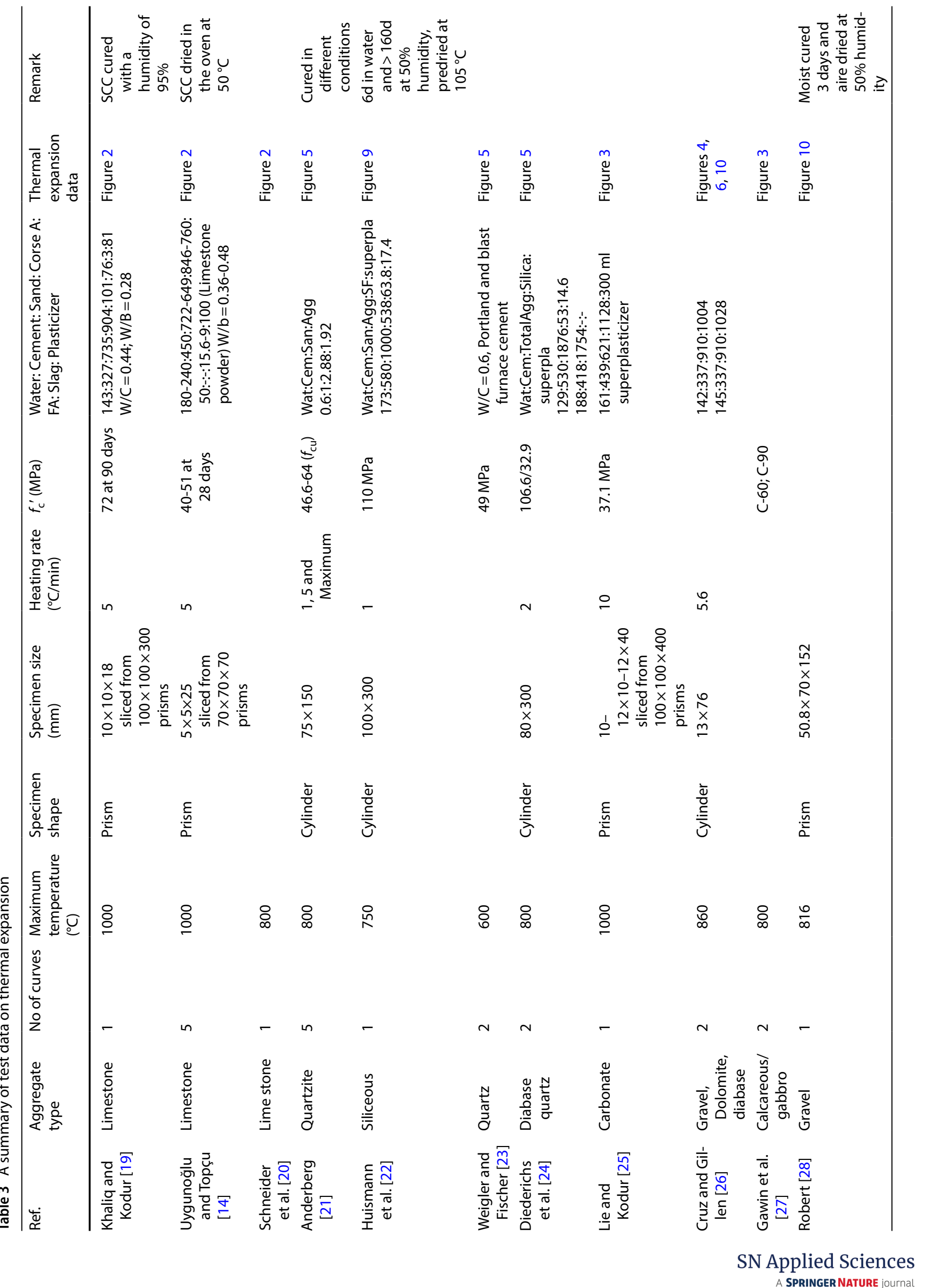


Research Article SN Applied Sciences (2019) 1:425 | https://doi.org/10.1007/s42452-019-0452-1

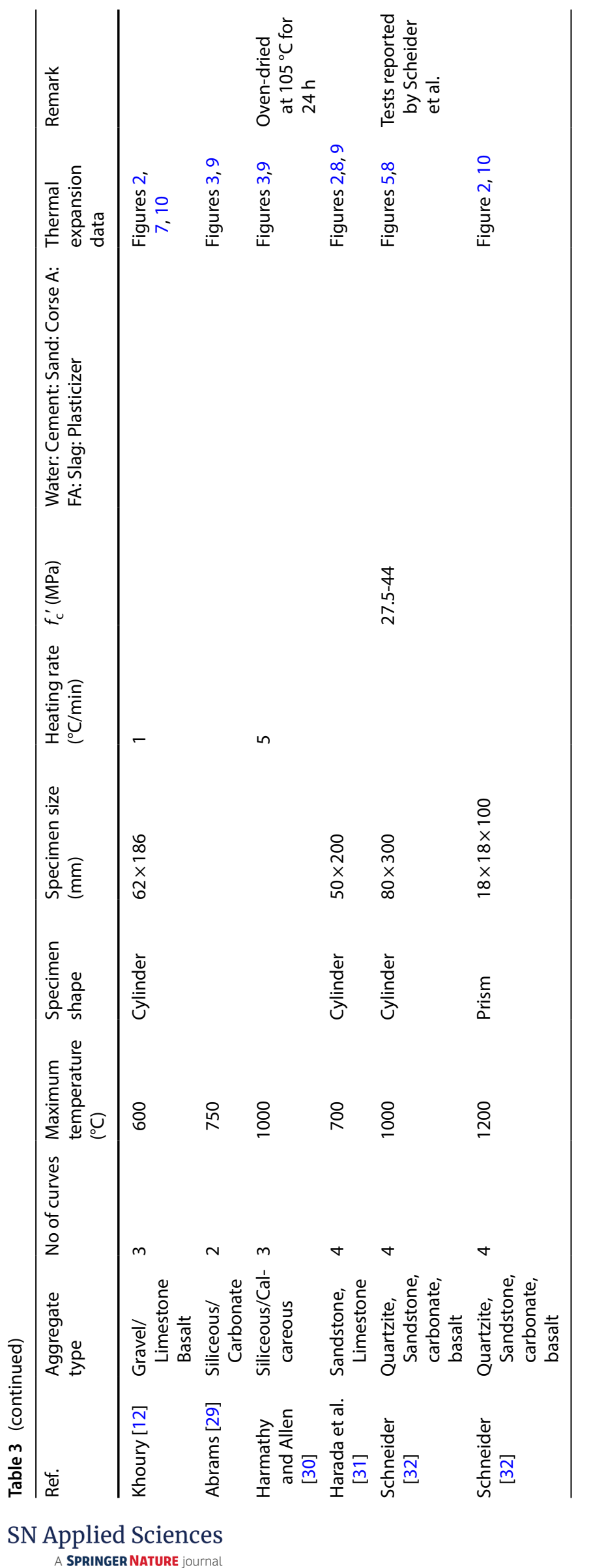




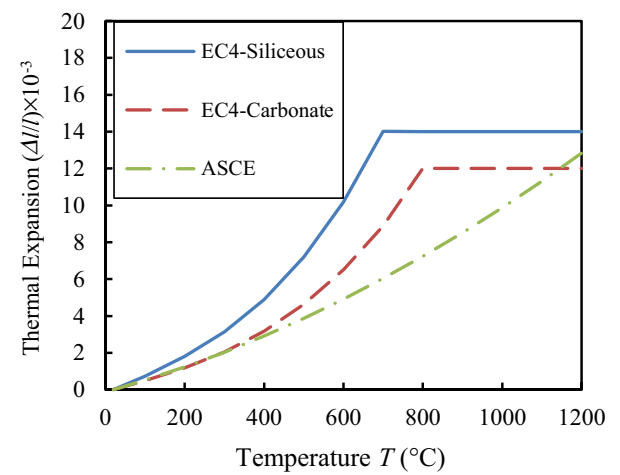

Fig. 1 Available models for concrete thermal expansion

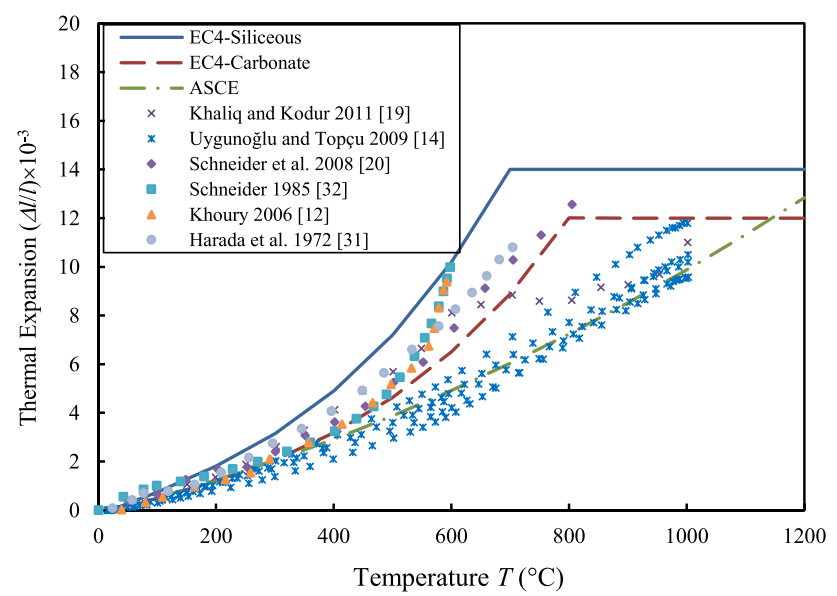

Fig. 2 Thermal expansion for concrete with Limestone coarse aggregate

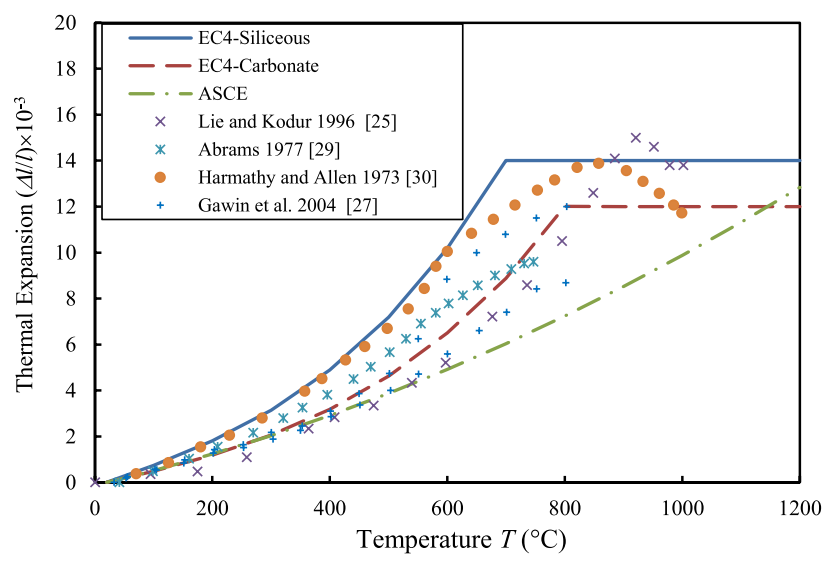

Fig. 3 Thermal expansion for concrete with Carbonate aggregate (without mentioning specific type)

limit for CTE of limestone while ASCE model gives a lower limit, however, no model gives the best simulation for the given data, Fig. 3 includes test result for carbonate coarse

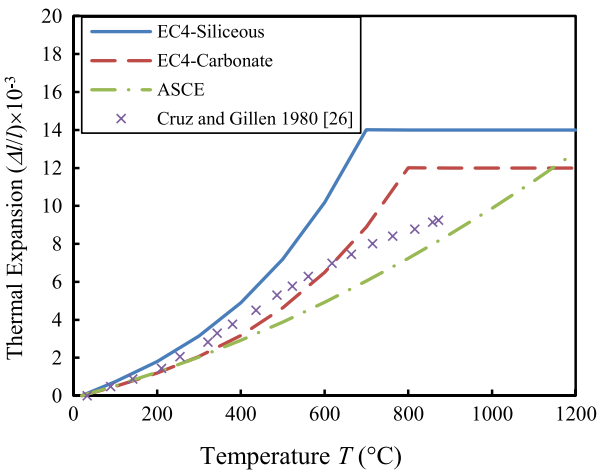

Fig. 4 Thermal expansion for concrete with Dolomite Coarse aggregate

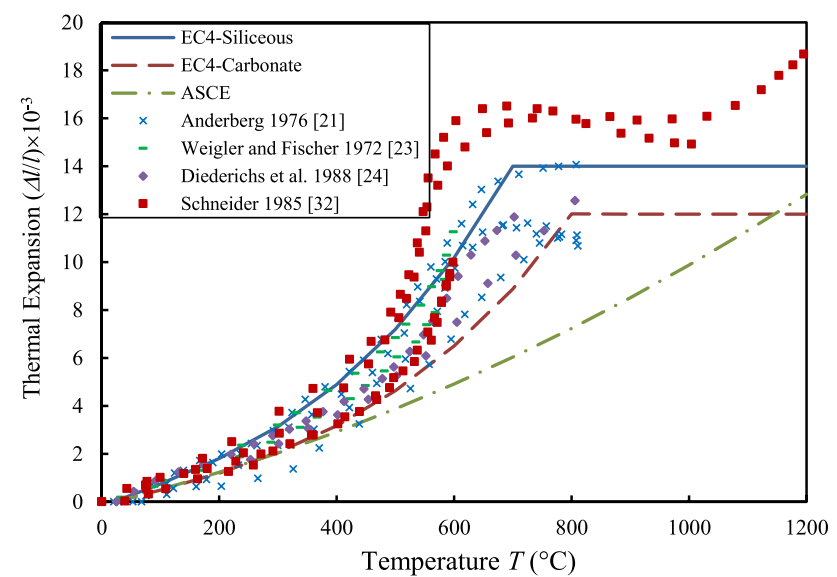

Fig. 5 Thermal expansion for concrete with Quartize Coarse aggregate

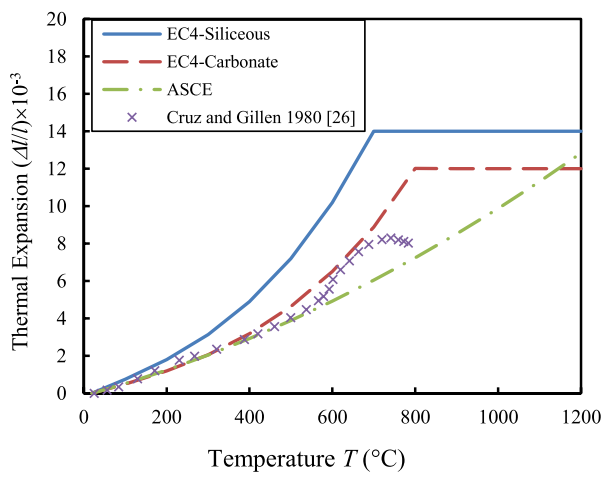

Fig. 6 Thermal expansion for concrete with Diabase Coarse aggregate

aggregate concrete $[25,27,29,30]$, however, the experimental program do not give details about the type of carbonate aggregate, similar case to Fig. 2 no model gives good representation for the data, Fig. 4 includes the result of CTE of dolomite concrete aggregate [26] which is best represented 


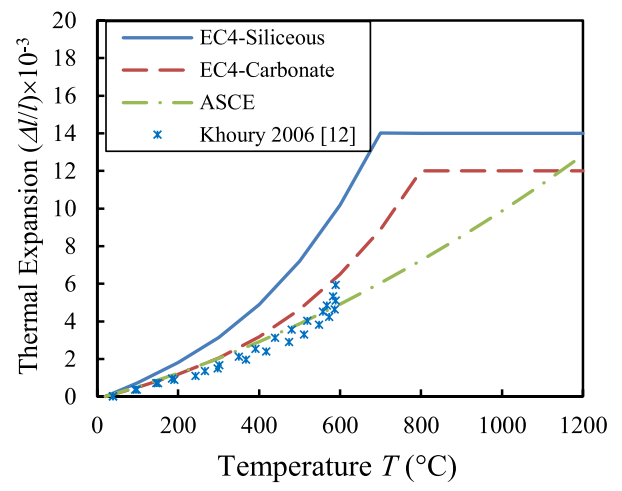

Fig. 7 Thermal expansion for concrete with Basalt Coarse aggregate

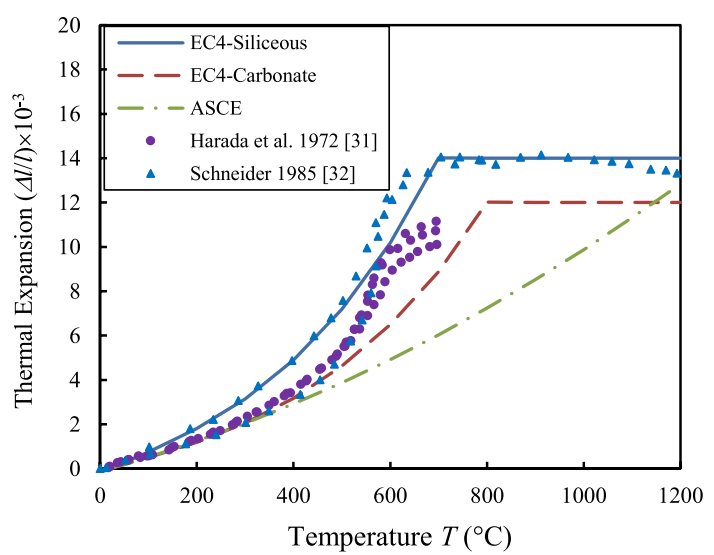

Fig. 8 Thermal expansion for concrete with Sandstone Coarse aggregate

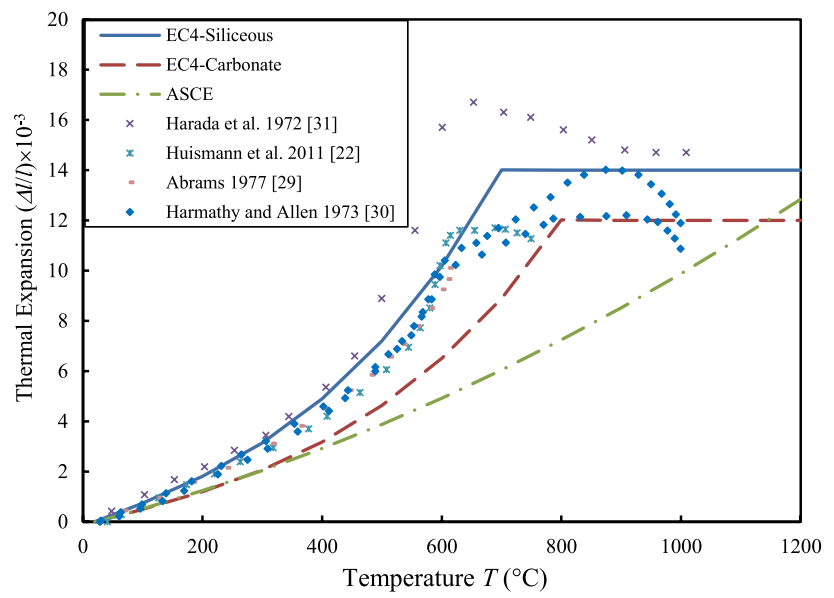

Fig. 9 Thermal expansion for concrete with Siliceous Coarse aggregate

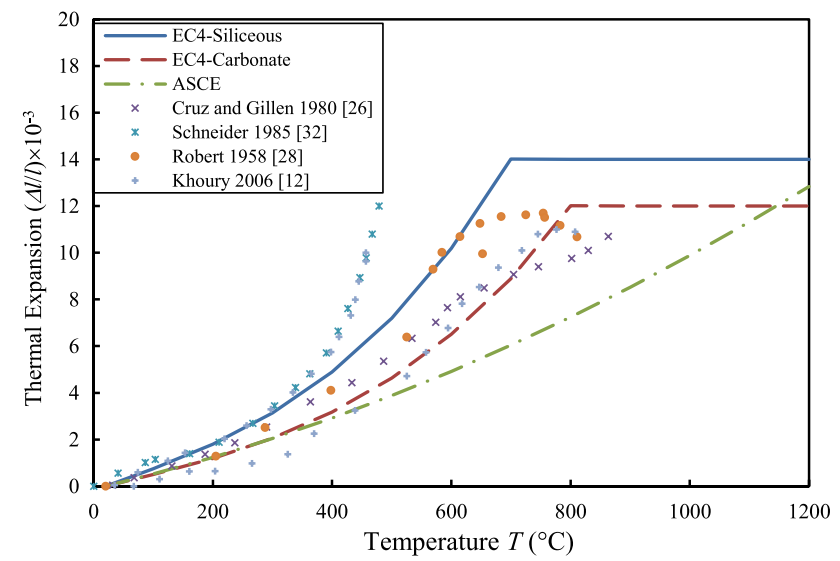

Fig. 10 Thermal expansion for concrete with Gravel Coarse aggregate

by Euro carbonate model, Fig. 5 includes quartize data [21, 23, 24, 32], it can be found from the figure that Euro Siliceous model represents an upper limit for this type of concrete aggregate, Fig. 6 [26] shows that Euro code carbonate model gives better simulation for the CTE of diabase aggregate concrete, Fig. 7 presents the basalt data [12] which is better simulated by ASCE model, Fig. 8 introduces the comparison of the available models with the sandstone data [31, 32], Fig. 8 shows that Euro siliceous model gives an upper limit for simulation of CTE of sandstone aggregate concrete, Fig. 9 introduces the test result for Siliceous coarse aggregate concrete $[22,29-31]$ but the experimental program did not give any specification about what siliceous aggregate type was used and it is notable that CTE of siliceous concrete is better simulated with Euro code siliceous model, no model could simulate accurately gravel CTE $[12,26,28,32]$ as can be seen in Fig. 10.

From the analysis of the previous curves, it can be seen that no model could accurately simulate CTE for various type of aggregate. The reason for that is summarized here. ASCE model ignores both aggregate type and saturation condition; ASCE proposes one model for all types of aggregate and saturation conditions which gives inaccurate simulation for the prediction of CTE. Although Euro code model takes into account the effect of aggregate type in the prediction of the coefficient of thermal expansion by proposing two models; one for Carbonate and another one for Siliceous aggregate, it ignores the effect of saturation conditions on CTE and it is not illustrated for each model which saturation condition that model is suitable for (saturated, partially saturated (partially dry) or oven dried condition). 


\section{Proposing new models for concrete thermal expansion}

The conclusion obtained from the previous section shows the need to propose a new model that can give better simulation for the given data. Five steps were followed in order to propose a simplified new model.

First step: which is already done in the previous section, this step is to evaluate the available models for prediction of CTE of concrete and as discussed before the available models cannot predict accurately the available test data for CTE which shows the need to develop a new model.

Second step: The data that were used in the previous section are divided into four groups taking into account the aggregate types and saturation conditions. The four groups are divided as follows: two main groups according to the aggregate type (carbonate and siliceous), each one of the main group is divided into another two subgroups based on saturation condition (partial dry (nearly 50-80\% humidity) and oven dry), so the four groups are: carbonate concrete with partial saturated (partial dry) saturation condition, carbonate concrete with oven dried saturation condition, siliceous concrete with partial saturated (partial dry) saturation condition, siliceous concrete with oven dried saturation condition.

Third step: is to select from the test data discussed in the previous section which aggregate can be classified as carbonate concrete and which aggregate can be classified as siliceous concrete. This step was done based on the data in Figs. 2, 3, 4, 5, 6, 7, 8, 9, 10 and its comparison with Euro code and ASCE models and by using the chemical composition for concrete coarse aggregate given in Table 1, it was found that Carbonate concrete groups contain mainly; Limestone, Dolomite, Basalt and Diabase as a coarse aggregate in there Mixes, while concrete that contains mainly; Quartzite and Sandstone aggregate are included in Siliceous concrete groups.

It should be noted that the CTE for the saturated condition was not included in the proposed models as there are limited test data available to propose a separate model for CTE of concrete at the saturated condition. However, Sakyi-Bekoe [40], Neville, Brooks [39] and Mindess et al. [41] stated that CTE of concrete at oven dried condition is slightly higher than CTE of concrete at saturated condition so for approximation it can be concluded that if it is required to calculate the CTE at saturated condition, similar value to the CTE at oven dried sample obtained from this study can be used. More experimental work should be done in future for determining CTE of concrete with saturated condition in order to give a better understanding of concrete thermal expansion at this saturation condition.
Fourth step: for each group, regression analysis was performed in order to develop the best-fit formula that can simulate CTE for that group and so four models determining CTE of concrete were developed representing the four groups that were discussed before.

Fifth step: is to check the accuracy of the proposed models, this is performed 1 st by comparing the prediction accuracy of these models and the available models (Euro code and ASCE model) against the available test result, 2nd by comparing the fire behaviour of concrete filled steel tube using the developed model and the fire test result of these columns, this step will be clearly indicated in the next few paragraphs.

Four models for calculating CTE were proposed for the four groups: Carbonate aggregate concrete with partially saturated condition, carbonate aggregate concrete with oven dry saturation condition, siliceous aggregate concrete with partially saturated condition and Siliceous aggregate concrete with oven dried condition. The four models are indicated in Eqs. 4, 5, 6 and 7 respectively.

Comparison between the four proposed models, Euro code model, ASCE model, and the test data are available in Figs. 11, 12, 13, 14 for each group respectively.

Specimens shape can affect the result of CTE [42], however, due to the limitation of test CTE results concerning the effect of specimens shape under different saturation condition and different coarse aggregate type, effect of specimens was not studied in this paper, however, prism shape specimens was mainly used in development of the proposed model for carbonate aggregate while cylinder was mainly used in developing the proposed model for siliceous aggregate.

$$
\begin{aligned}
\varepsilon_{\mathrm{th}}= & -2.02 * 10^{-11} \mathrm{~T}^{3}+3.42 * 10^{-8} \mathrm{~T}^{2} \\
& -1.06 * 10^{-6} \mathrm{~T}+2.79 * 10^{-4} 20^{\circ} \mathrm{C}<\mathrm{T} \leq 1000^{\circ} \mathrm{C} \\
\varepsilon_{\mathrm{th}}= & 12.7 * 10^{-3} \quad 1000{ }^{\circ} \mathrm{C}<\mathrm{T} \leq 1200^{\circ} \mathrm{C}
\end{aligned}
$$

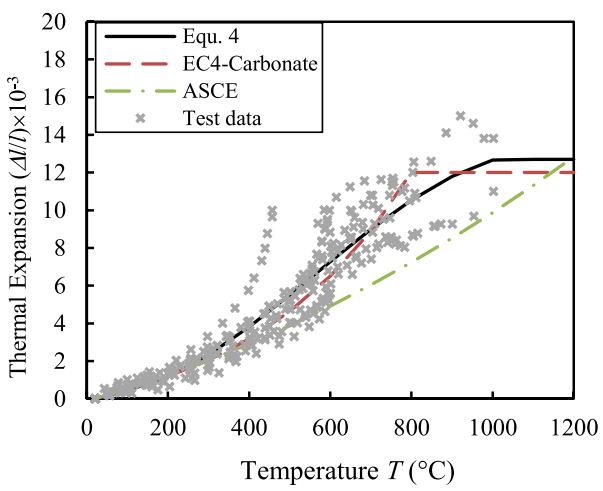

Fig. 11 Comparison between proposed Eq. 4, Eurocode carbonate model and ASCE model for carbonate aggregate partial dry curing condition 


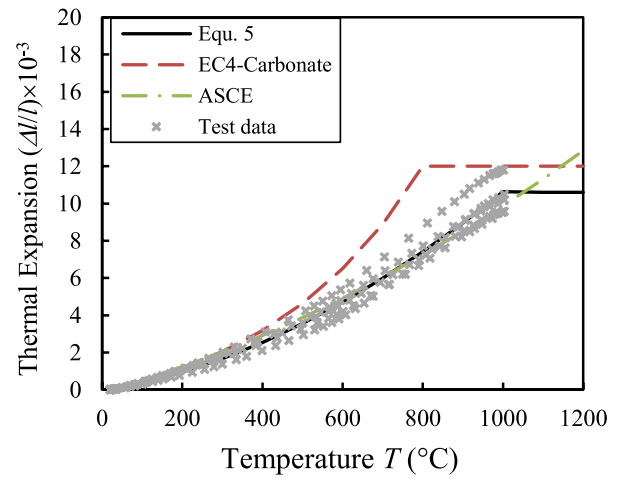

Fig. 12 Comparison between proposed Eq. 5, Eurocode carbonate model and ASCE model for carbonate aggregate oven dry curing condition

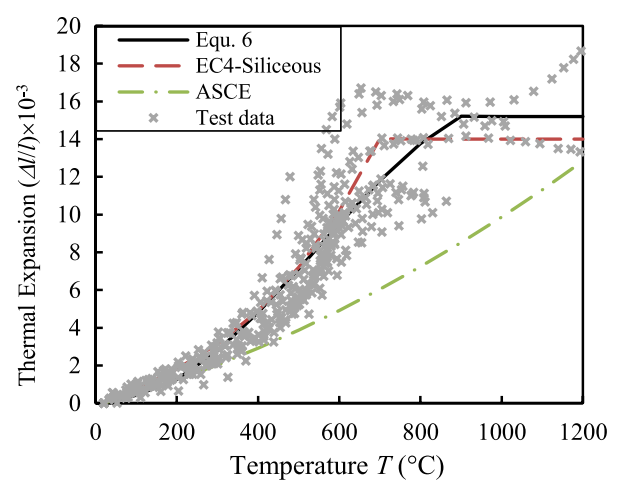

Fig. 13 Comparison between proposed Eq. 6, Eurocode siliceous model and ASCE model for siliceous aggregate partial dry curing condition

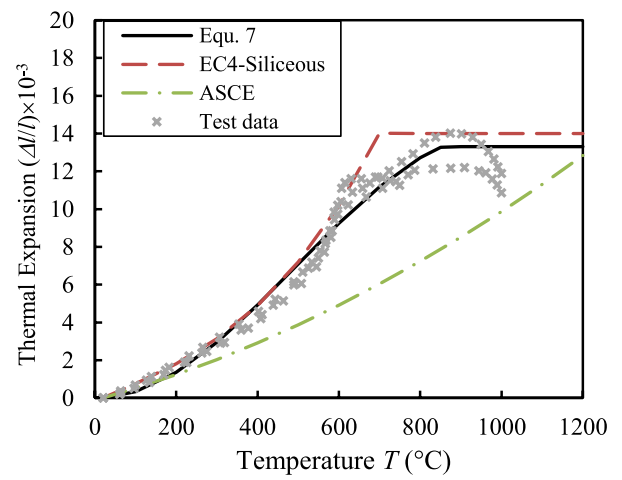

Fig. 14 Comparison between proposed Eq. 7, Eurocode siliceous model and ASCE model for siliceous aggregate oven dry curing condition

$$
\begin{aligned}
\varepsilon_{\mathrm{th}}= & -5.08 * 10^{-13} \mathrm{~T}^{3}+7.73 * 10^{-9} \mathrm{~T}^{2} \\
& +3.45 * 10^{-6} \mathrm{~T}-4.03 * 10^{-5} \\
& 20^{\circ} \mathrm{C}<\mathrm{T} \leq 1000{ }^{\circ} \mathrm{C}
\end{aligned}
$$

$$
\begin{aligned}
\varepsilon_{\text {th }}= & 10.6 * 10^{-3} \quad 1000^{\circ} \mathrm{C}<\mathrm{T} \leq 1200^{\circ} \mathrm{C} \\
\varepsilon_{\text {th }}= & -3.38 * 10^{-11} \mathrm{~T}^{3}+5.51 * 10^{-8} \mathrm{~T}^{2}-5.88 * 10^{-6} \mathrm{~T} \\
& +5.01 * 10^{-4} \quad 20^{\circ} \mathrm{C}<\mathrm{T} \leq 900^{\circ} \mathrm{C} \\
\varepsilon_{\text {th }}= & 15.2 * 10^{-3} \quad 900^{\circ} \mathrm{C}<\mathrm{T} \leq 1200^{\circ} \mathrm{C} \\
\varepsilon_{\text {th }}= & -3.24 * 10^{-11} \mathrm{~T}^{3}+4.80 * 10^{-8} \mathrm{~T}^{2}-1.82 * 10^{-6} \mathrm{~T} \\
& +6.48 * 10^{-5} \quad 20^{\circ} \mathrm{C}<\mathrm{T} \leq 850^{\circ} \mathrm{C} \\
\varepsilon_{\text {th }}= & 13.3 * 10^{-3} \quad 850^{\circ} \mathrm{C}<\mathrm{T} \leq 1200^{\circ} \mathrm{C}
\end{aligned}
$$

Table 4 shows the comparison between the accuracy of the CTE prediction for each one of the proposed models and Euro code mode (Carbonate and Siliceous) and ASCE model through the R-Squared $\left(R^{2}\right)$ value for each model, it can be seen from the table, that the proposed models give better prediction for all types of aggregate (carbonate and siliceous) and for all saturation conditions (partially dry and oven dried condition).

The newly proposed models were evaluated against previous fire test results which were performed on concrete filled steel tube (CFST) columns. The test result was prepared by Lie, Chabot [43]. The test result was compared with the result of finite element (FE) model that was presented by Tao et al. [44]. The FE model was performed using ABAQUS software [45].

Two columns were chosen from the experimental results ( $\mathrm{C} 13$ and $\mathrm{C44}$ ), one of them contains siliceous aggregate concrete (C13) and the other contains carbonate aggregate concrete (C44), the details of the tested columns are shown in Table 5. In Table 5, $L$ is the total length of the column in $\mathrm{mm}, L O$ is the heated length (in $\mathrm{mm}$ ) of the column inside the furnace during the experiments, $D$ is the outer column diameter in $\mathrm{mm}, t$ is the steel tube thickness in $\mathrm{mm}$, fy is the yielding strength of steel tube in $\mathrm{MPa}, \mathrm{fc}^{\prime}$ is the compressive strength of concrete in $\mathrm{MPa}$, FF indicates fixed end condition for the column ends, load level is the ratio between the applied load on the column during the experiment and the ultimate load capacity of the columns at ambient temperature, FRR is the fire resistance of the column in minutes, which mean the time at which the column cannot carry any more load under fire condition and the deformation of the column began to increase dramatically.

Figure 15 compares the time-vertical displacement curve for the test result and the FE model, where the vertical axis is the vertical displacement at the top of the columns in $\mathrm{mm}$ and the horizontal axis is the time during fire exposure in minutes. In Fig. 15, "Test" indicates the time-vertical displacement curve obtained from experimental results, while "FE-EC4" and "FE-proposed" indicate 
Table 4 Comparison between proposed models, Eurocode (carbonate and Siliceous) models and ASCE model

\begin{tabular}{llll}
\hline Case: & Carbonate aggregate, Partial dry & & \\
Model & Equation 4 & Eurocode Carbonate model & ASCE model \\
$\mathrm{R}^{2}$ & 0.89 & 0.86 & 0.64 \\
Case: & Carbonate aggregate, oven dry & & \\
Model & Equation 5 & Eurocode Carbonate model & ASCE model \\
$\mathrm{R}^{2}$ & 0.98 & 0.69 & 0.97 \\
Case: & Siliceous aggregate, Partial dry & & \\
Model & Equation 6 & Eurocode Siliceous model & ASCE model \\
$\mathrm{R}^{2}$ & 0.89 & 0.88 & 0.34 \\
Case: & Siliceous aggregate, Oven dry & & \\
Model & Equation 7 & Eurocode Siliceous model & ASCE model \\
$\mathrm{R}^{2}$ & 0.97 & 0.92 & 0.33 \\
\hline
\end{tabular}

Table 5 Details of the columns used in verification of the proposed model [43]

\begin{tabular}{llllllllllll}
\hline Col. & $L(\mathrm{~mm})$ & $L 0(\mathrm{~mm})$ & $D(\mathrm{~mm})$ & $t(\mathrm{~mm})$ & $f y(\mathrm{MPa})$ & $f \mathrm{c}^{\prime}(\mathrm{MPa})$ & $\begin{array}{l}\text { Concrete Coarse } \\
\text { aggregate type }\end{array}$ & End condition & Load (KN) & Load level & FRR (min) \\
\hline C13 & 3810 & 3200 & 219.1 & 4.78 & 322.1 & 32.3 & Quartz & FF & 384 & 0.27 & 102 \\
C44 & 3810 & 3200 & 273.1 & 6.35 & 350 & 38.7 & Carbonate stone & FF & 715 & 0.27 & 178 \\
\hline
\end{tabular}

Fig. 15 Comparison between Eurocode-4 and the proposed model with previous fire test results on composite columns

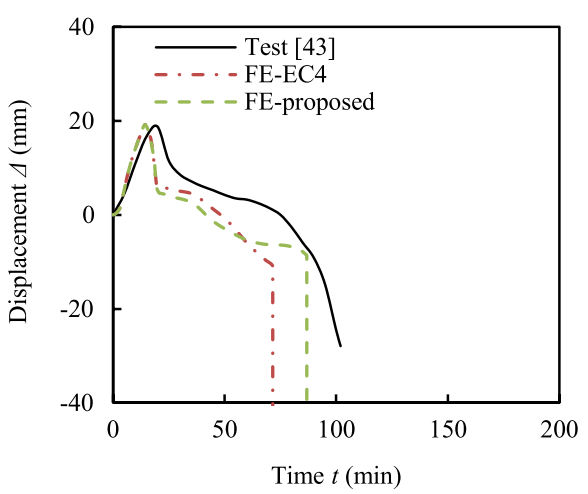

(a) $\mathrm{C} 13$

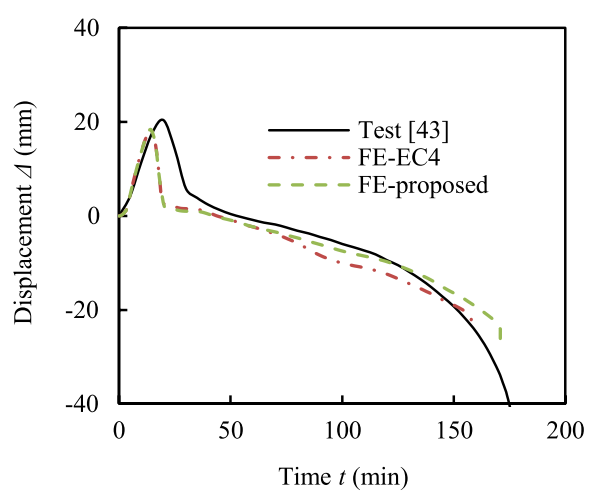

(b) $\mathrm{C} 44$ the results obtained from FE model when using Eurocode-4 and proposed expansion models respectively.

From Fig. 15, it can be seen that the proposed models give a reasonable and better prediction for the fire behaviour and fire resistance of the selected columns (C13 and C44) compared with the model that used Eurocode-4 CTE.

\section{Conclusions}

In this paper the available test data that were performed on the concrete CTE are collected, these data were used in evaluating the available concrete CTE models. The following conclusions could be drawn:
- Neither Euro code model nor ASCE model can accurately predict concrete the CTE for different types of aggregate as both models ignore the saturation conditions, while ASCE model ignores also coarse aggregate type.

- More experimental work should be done to investigate the effect of specimens shape under different saturation condition and for different coarse aggregate concrete,

- More experimental work should be done in order to give better prediction for concrete CTE at saturated condition

- Four models were proposed for the following cases: Carbonate with partial dry (saturated) condition, carbonate with oven dry saturation condition, siliceous 
partially dry (saturated) and siliceous oven dried saturation condition.

- Based on the comparison with previous test results on $\mathrm{CTE}$, it was found that the proposed models give more accurate result compared to that proposed by Euro code model and ASCE model.

- Another comparison was made between the proposed models and Eurocode-4 concrete CTE models, this comparison was between the fire test results of concrete filled steel tube columns and FE model using Eurocode-4 CTE model once and then using the proposed model another time, it was found that the proposed models give closer result to the experimental test results compared to Eurocode-4 CTE model.

Acknowledgements The author would like to deeply thank Prof. Zhong Tao for his valuable discussions on the paper.

\section{Compliance with ethical standards}

Conflict of interest The authors declare that they have no conflict of interest.

\section{References}

1. Peng G-F, Sammy YNCSYN, Song Q-Mb, Yi Q-X (2006) Effect of High temperature on concrete: a review. Key Eng Mater 302-303:138-149

2. Naus DJ (2006) The effect of elevated temperature on concrete materials and structures-a literature review. Oak Ridge National Lab. (ORNL), Oak Ridge, TN (United States)

3. Hong S, Varma AH (2009) Analytical modeling of the standard fire behavior of loaded CFT columns. J Constr Steel Res 65(1):5469. https://doi.org/10.1016/j.jcsr.2008.04.008

4. Espinos A, Romero ML, Hospitaler A (2010) Advanced model for predicting the fire response of concrete filled tubular columns. J Constr Steel Res 66(8):1030-1046. https://doi.org/10.1016/j. jcsr.2010.03.002

5. AlJ (1997) Recommendations for design and construction of concrete filled steel tubular structures. Architectural Institute of Tokyo, Japan

6. Eurocode-4 (2005) Design of composite steel and concrete structures, Part 1-2, General rules-structural fire design. BS EN 1994-1-2: 2005. British Standards Institution, London

7. ASCE (1992) Structural fire protection. Manual No. 78. ASCE committee on fire protection, structural division, American Society of Civil Engineers, New York, USA

8. Gonilho Pereira C, Castro-Gomes J, Pereira de Oliveira L (2009) Influence of natural coarse aggregate size, mineralogy and water content on the permeability of structural concrete. Constr Build Mater 23(2):602-608. https://doi.org/10.1016/j.conbu ildmat.2008.04.009

9. Naik TR, Kraus RN, Kumar R (2011) Influence of types of coarse aggregates on the coefficient of thermal expansion of concrete.
J Mater Civ Eng 23(4):467-472. https://doi.org/10.1061/(ASCE) MT.1943-5533.0000198

10. Al-Juboury Al, McCann T, Ghazal MM (2009) Provenance of Miocene sandstones in northern Iraq: constraints from framework petrography, bulk-rock geochemistry and mineral chemistry. Russ Geol Geophys 50(6):517-534. https://doi. org/10.1016/j.rgg.2008.09.005

11. Tasong WA, Cripps JC, Lynsdale CJ (1998) Aggregate-cement chemical interactions. Cem Concr Res 28(7):1037-1048. https ://doi.org/10.1016/S0008-8846(98)00067-2

12. Khoury GA (2006) Strain of heated concrete during two thermal cycles. Part 1: strain over two cycles, during first heating and at subsequent constant temperature. Mag Concr Res 58(6):367-385. https://doi.org/10.1680/macr.2006.58.6.367

13. Campbell-Allen D, Desai PM (1967) The influence of aggregate on the behaviour of concrete at elevated temperatures. Nucl Eng Des 6(1):65-77. https://doi.org/10.1016/00295493(67)90047-7

14. Uygunoğlu T, Topçu IB (2009) Thermal expansion of selfconsolidating normal and lightweight aggregate concrete at elevated temperature. Constr Build Mater 23(9):3063-3069. https://doi.org/10.1016/j.conbuildmat.2009.04.004

15. Das SK, Sharma AK, Parida FC, Kasinathan N (2009) Experimental study on thermo-chemical phenomena during interaction of limestone concrete with liquid sodium under inert atmosphere. Constr Build Mater 23(11):3375-3381. https:// doi.org/10.1016/j.conbuildmat.2009.06.021

16. Bagampadde U, Isacsson U, Kiggundu BM (2005) Influence of aggregate chemical and mineralogical composition on stripping in bituminous mixtures. Int J Pavement Eng 6(4):229 239. https://doi.org/10.1080/10298430500440796

17. Saffarini GA, Jarrar GH (1998) Quantifying the chemical variability of a Precambrian diabase from south Jordan using stochastic techniques: a proposal. J Volcanol Geotherm Res 86(1):199-217. https://doi.org/10.1016/S0377-0273(98)00079 $-1$

18. Antonov GI, Nedosvitii VP, Kulik AS, Semenenko OM (2004) Stabilized dolomite refractories. Refract Ind Ceram 45(3):160-164. https://doi.org/10.1023/b:refr.0000036722.20179.39

19. Khaliq W, Kodur V (2011) Thermal and mechanical properties of fiber reinforced high performance self-consolidating concrete at elevated temperatures. Cem Concr Res 41(11):1112-1122. https ://doi.org/10.1016/j.cemconres.2011.06.012

20. Schneider U, Schneider M, Franssen J (2008) Consideration of nonlinear creep strain of silicious concrete on calculation of mechanical strain under transient temperatures as a function of load history. In: Proceedings of the fifth international conference structures in fire, pp 463-476

21. Anderberg $Y$ (1976) Stress and deformation characteristics of concrete at high temperatures, 2. Experimental invesitation and material behavour model. Bulletin 54 Sweden (Lund): Lund Institute of Technology, Lund, Sweden

22. Huismann S, Weise F, Meng B, Schneider U (2011) Influence of polypropylene fibres on the thermal strain of high strength concrete at high temperatures. Journal of Structural Fire Engineering 2(3):173-180. https://doi.org/10.1260/2040-2317.2.3.173

23. Weigler H, Fischer R (1972) Influence of high temperatures on strength and deformation of concrete. ACl, Special Publication 34. https://doi.org/10.14359/18082

24. Diederichs U, Jumppanen U, Penttala V (1988) Material properties of high strength concrete at elevated temperatures. IABSE 13th congress, Helsinki, pp 489-494 
25. Lie TT, Kodur VKR (1996) Thermal and mechanical properties of steel-fibre-reinforced concrete at elevated temperatures. Can J Civ Eng 23(2):511-517. https://doi.org/10.1139/196-055

26. Cruz CR, Gillen M (1980) Thermal expansion of Portland cement paste, mortar and concrete at high temperatures. Fire Mater 4(2):66-70. https://doi.org/10.1002/fam.810040203

27. Gawin D, Pesavento F, Schrefler BA (2004) Modelling of deformations of high strength concrete at elevated temperatures. Mater Struct 37(4):218. https://doi.org/10.1007/bf02480631

28. Robert $P$ (1958) Some physical properties of concrete at high temperatures. ACI 54 (4).https://doi.org/10.14359/11472

29. Abrams M (1977) Performance of concrete structures exposed to fire. Research and Development Bulletin RD06001 D, Portland Cement Association, Chicago

30. Harmathy TZ, Allen LW (1973) Thermal Properties of Selected Masonry Unit Concretes. ACI 70 (2). https://doi.org/10.14359 $/ 11193$

31. Harada T, Takeda J, Yamane S, Furumura F (1972) Strength, elasticity and thermal properties of concrete subjected to elevated temperatures. Special Publication 34. https://doi.org/10.14359 $/ 18077$

32. Schneider U (1985) Properties of materials at high temperaturesconcrete. RILEM 44-PHT, University of Kassel, Kassel, Germany

33. Nielsen CV (2003) Experimental investigation of combined thermal and mechanical behaviour of danish and swedish concrete subject to high temperatures. Nordic Concrete Research 30:1-20

34. Naus DJ (2010) A compilation of elevated temperature concrete material property data and information for use in assessments of nuclear power plant reinforced concrete structures. United states Nuclear Regulatory commission, NRC Job Code N6511

35. Kodur VKR, Sultan MA (2003) Effect of temperature on thermal properties of high-strength concrete. J Mater Civ Eng 15(2):101107. https://doi.org/10.1061/(ASCE)0899-1561(2003)15:2(101)
36. Khoury GA, Grainger BN, Sullivan PJE (1985) Strain of concrete during first heating to $600^{\circ} \mathrm{C}$ under load. Mag Concr Res 37(133):195-215. https://doi.org/10.1680/macr.1985.37.133.195

37. Takeuchi M, Hiramoto $M$, Kumagai N, N. Y, Kodaira A, Sugiyama $K$ (1993) Material Properties of Concrete and Steel Bars at Elevated Temperatures. SMiRT-12, Elsivier science publishers BV

38. Abrams MS (1979) Behavior of Inorganic Materials in Fire. Research and development bulletin RD06701 M, American Society for Testing and Materials

39. Neville AM, Brooks JJ (1987) Concrete Technology. Essex, UK: Longman Scientific and Technical, UK

40. Sakyi-Bekoe KO (2008) Assessment of the coefficient of thermal expansion of alabama concrete. The Graduate Faculty of Auburn University, Auburn

41. Mindess S, Young JF, Darwin D (2003) Concrete, 2nd edn. Prentice Hall, Upper Saddle River New Jersey

42. Yang S, Kim N, Kim J, Park J (2003) Experimental measurement of concrete thermal expansion, vol 5

43. Lie TT, Chabot M (1992) Experimental studies on the fire resistance of hollow steel columns filled with plain concrete. IRC Internal Report No 611, National Research Council of Canada, Institute for Research in Construction, Ottawa, Ontario

44. Tao Z, Ghannam M, Song T-Y, Han L-H (2016) Experimental and numerical investigation of concrete-filled stainless steel columns exposed to fire. J Constr Steel Res 118:120-134. https:// doi.org/10.1016/j.jcsr.2015.11.003

45. ABAQUS (2012) ABAQUS standard user's manual, Version 6.12

Publisher's Note Springer Nature remains neutral with regard to jurisdictional claims in published maps and institutional affiliations. 